\title{
O CETICISMO DO NARRADOR NA OBRA "A CIDADE E AS SERRAS" FRENTE À PROBLEMÁTICA CIDADE X CAMPO
}

Fernando Ferreira da Cunha Neto Universidade Federal de Minas Gerais

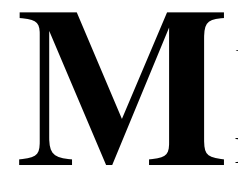

uito já foi dito sobre a obra de Eça de Queirós, $A$ Cidade e as Serras, no que tange à problemática Campo X Cidade. Alguns preferiram enfocá-la como um idílio, uma apologia à vida rural e à simplicidade das coisas ditas "naturais", saudosa de um tempo em que o homem extraía da terra tudo de que necessitava. Uma visão que, talvez, pudesse ser relativizada. Relativizada porque o romance de Eça de Queirós remonta ao fim do século XIX, época em que já não se encaixavam mais as máximas do romantismo.

O século XIX se nos apresenta como um período de intensas transformações. O homem havia sido capaz de criar engenhos mecânicos que o podiam transportar a todas as partes do mundo. Em terra, os trens transportavam passageiros, bagagens, notícias, etc. Entre os continentes, os vapores iam e vinham num frêmito mercante antes inimaginável. Até mesmo à distância as pessoas podiam se falar usando uma das maravilhas da tecnologia: o telefone. Mas, esta mesma fase, foi, também, bastante conturbada. Um passado arcaico, senhorial, já havia sido golpeado por muitas revoluções - o século XIX, desde a década de vinte até seu último quartel, havia sido o período em que ocorreram as chamadas Revoluções Liberais. Em um período histórico tão conturbado como este, é-nos difícil imaginar uma apologia à vida campestre e, principalmente, nos termos em que o narrador nos descreve, a Tormes, torrão natal do nosso protagonista, o Jacinto. 
O narrador-personagem, ao mesmo tempo em que descreve a quinta de Tormes como o rincão natal de nosso herói, o lugar onde estavam plantados, desde mais de quatrocentos anos, os marcos de seus antepassados, fidalgos de cepa, também descreve a mesma Tormes como hostil. Local onde ocorrem tormentas que transformam as serras em cascatas, varrem suas construções, fazem-nas afundar na lama e desalojam os ossos das bravas e indefectíveis gerações passadas. Para demonstrá-lo, ele - o narrador - colhe os depoimentos dos agregados da quinta de Tormes. Eles dizem textualmente:

“(...) E depois eu sempre quero ver o Snr. D. Jacinto, aqui no Inverno, com o nevoeiro a subir do rio logo pela manhã, e a friagem a traspassar os ossos, e ventanias que atiram carvalheiras de raízes ao ar, e chuvas e chuvas que se desfaz a serra!..."1

Nosso narrador-personagem ofusca também a idéia de um brilho impoluto, que se perpetua através dos séculos, quando descreve o desleixo e o estado de degradação em que se encontram as casas dos agregados da quinta de Tormes e a debilidade física dos mesmos vassalos, para que usemos uma palavra adequada ao espírito senhorial.

O narrador de A Cidade e as Serras parece buscar uma via alternativa ao elogio à vida no campo e também à apologia ao brilho da civilização. Esboça um retrato mediatizado da Tormes Secular. Se elogia-lhe o ar agreste, os frutos suculentos, as águas cristalinas, o narrador o faz pela boca do seu príncipe da grã-ventura. Este não enxerga os problemas de seu "feudo". Ele é um homem que vive dos foros que a terra lhe propicia. Assim como viveram sucessivas gerações de Jacintos. Jacinto nem ao menos perscruta ao seu redor para descobrir quais seriam as soluções mais adequadas às chagas que a secular Tormes apresenta. Sai distribuindo benesses aos seus

1 QUEIROZ, Eça de. A Cidade e as Serras. Lello \& Irmão-Editores, Lisboa,1950 p.214. 
agregados, como o nobre pródigo, que auferira riquezas incontáveis, após a apropriação de despojos, os quais recompensam o vencedor de uma batalha. Jacinto sonha também em modernizar a Tormes, transformá-la em usina produtora de queijos de paladar apurado. A estas idéias do príncipe da grã-ventura, o nosso narradorpersonagem atira as dúvidas do empregado da quinta, encarregado de tomar as providências necessárias:

“(...) não surgia dificuldade, risonhamente murmurado pelo Melchior, ou exclamada, com respeitoso pasmo pelo Silvério, que ele (Jacinto) não afastasse brandamente(...) como um galho de roseira brava atravessado numa vereda.

Aquelas rochas, além, empecendo? Que se arrancassem! Um vale importuno dividia dois campos? Que se atulhasse. O Silvério suspirava, enxugando sobre a escura calva um suor quase de angústia." ${ }^{2}$

Ao que o empregado da quinta interpõe: "Pois, Snr. Fernandes, se toda esta grandeza vai por diante, sempre lhe digo que o Snr. D. Jacinto enterra aqui na serra dezenas de contos...Dezenas de contos."

O nosso narrador-personagem atira seu olhar cético a quase tudo que descreve. Descrê de tudo e de todos. E quando deseja esboçar, ainda que seja por fugazes instantes, qualquer vislumbre de otimismo não usa a própria boca. Usa a do seu príncipe da grã-ventura, o personagem Jacinto. É o pueril Jacinto, figura como que extraída de uma novela cavalheiresca, sonhador, e eu diria, até mesmo, nas falas do nosso narrador-personagem, romântico, quem esboça, quem planeja, quem pensa levar a cabo seus sonhos. Zé Fernandes simplesmente lhe segue os passos como uma sombra. Descreve-lhe os gestos e até mesmo seus sentimentos. Pouco se pronuncia. Mas, no pouco que se manifesta, atira às ações do nosso herói, à sua terra e aos seus costumes, um olhar de desencanto e de ceticismo.

2 Idem. p. 213.

3 Idem. p. 213. 
Mas, se nos limitássemos a discorrer sobre a Tormes, poderíamos cair no extremo oposto das primeiras análises da obra de Eça de Queirós. Da apologia à vida campestre ao elogio do "homus urbanus". A hipótese, se contrária, seria a de que o narradorpersonagem havia eleito a cidade como o "locus amoenus". Local, por excelência, onde a grandeza do espírito humano pudesse desabrochar. A caverna luminosa destinada a ser o lugar perfeito para a vivenda do homem. Entretanto, ele não o faz. Ao contrário, atira à cidade e a todos os seus aparatos, exemplares genuínos do esplendor da civilização, o seu ceticismo. Mais que um olhar cético, ele atira à morada urbana uma fina ironia. Senão vejamos.

Zé Fernandes e o seu príncipe da grã-ventura habitavam o 202 da Champs Elisée, na gloriosa e decantada Paris de fins do século XIX. Lá tudo resplandecia. Dos cristais aos recém-inaugurados lustres que irradiavam a energia elétrica, maravilha da civilização. Tinham até o aparelho que lhes possibilitava falar com pessoas que estavam a quilômetros de distância, o telefone. Possuíam o telégrafo e um incontável número de obras que tentavam abarcar todos os ramos da Ciência, ente tão caro e dignificado pelos apologistas do progresso no século XIX. Jacinto e Zé Fernandes promovem festas fabulosas às quais acorre a fina flor da sociedade parisiense.

Apesar de todo o fulgor descrito anteriormente, o imenso aparato tecnológico por vezes falha. A água quente, que devia correr submissa por canos especiais, intempestivamente revolta-se e se esparrama por todos os cantos. Encharca tapetes caríssimos, quase fere aos seus senhores. As luzes costumam apagar-se e deixar tudo às escuras. Jacinto e Zé Fernandes chegam a ter um princípio de incêndio no 202.

Um dos trechos que é bastante elucidativo do tom jocoso com que o nosso narrador-personagem trata a maravilhosa parafernália, a qual simboliza a modernidade dos tempos, é o seguinte: Jacinto tenta utilizar um instrumento recém-adquirido, cuja função era propiciar um melhor manuseio de papéis. Não tem êxito e acaba por se ferir. Deixa gotículas de seu sangue, advindo de quatrocentos 
anos de brava fidalguia de cepa, sobre as folhas. O tom da descrição extrapola o jocoso. Leva ao ridículo e ao riso.

Um outro aspecto do ceticismo do narrador-personagem, com relação às luzes do século XIX é o fato de, na biblioteca do 202, estarem amontoados centenas de livros de ramos do conhecimento os mais díspares possíveis. Astronomia, Economia Política, Filosofia Clássica, Biologia, Tratados de Mecânica, Arte, etc. Qual seria a conexão de todos estes saberes ? Estariam eles propiciando a aurora de um novo tempo ou seriam simples máscaras que encobririam uma sociedade também corroída por dentro?

Outro indício do olhar de desencanto que lança o nosso narrador, sobre a cidade, é o que se concretiza quando ele e o seu príncipe da grã-ventura sobem a Montmartre e vislumbram a cidade. Enxergam, então, a dura realidade que os cercava: o fausto, o belo, o elegante, o "bem-cheiroso" em contraste com a miséria e a pobreza. Os dois, lá do alto, a um só tempo, vêem os palacetes elegantes e os casebres da gente pobre e humilde. Gente esta que dava no seu dia-a-dia o próprio suor para que a civilização resplandecesse em glória. Quão ferino e cortante é este trecho da obra de Eça de Queirós. Outros trechos da obra podem ser agregados a esta discussão. Elegi dois que me parecem cruciais.

O primeiro é o trecho em que o narrador nos conta um episódio ocorrido em uma festa no 202. O elevador que fazia ascender da cozinha ao salão o peixe, prato especialmente destinado ao grão-duque, enguiça e não sobe, a despeito de todos os esforços que imprimem ao botão de controle. O grão-duque recusa qualquer substitutivo ao seu prato predileto e vai fisgá-lo com um gancho atado a um cabo. A cena conduz ao ridículo e chega a ser hilariante.

O segundo é o trecho em que o homem que fora responsável pela junção dos ossos das sucessivas gerações de Jacintos diz que os ossos haviam se misturado, alguns estavam perdidos e que, por isso, ele os juntara a esmo. Ou seja, provavelmente jaziam nas novas sepulturas, dignas tumbas construídas para fidalgos que vinham de cinco séculos, ossos dos honrados Jacintos misturados a outros não 
tão ilustres. Nos dois espaços, cidade e campo(serras) temos a fina ironia que denota o tom cético com que o nosso narradorpersonagem esculpe os dois espaços. O peixe emperrado a meio caminho, dentro do fosso do elevador, quase que sepultado pela escuridão. Os ossos desenterrados e arrastados pela tormenta e sepultados ironicamente pela lama. Quando recuperados, parte deles, não se pode reconstituir por completo os esqueletos. A fidalguia das sucessivas gerações de Jacintos havia sido quebrada.

Apesar de tudo o que as Serras lhe apresentavam em termos de desconforto, de atraso científico, de incivilizado, etc, o nosso Jacinto da Serra, tal qual a flor do mesmo nome, deita raízes na Tormes Secular. Quer florescer na sua quinta de quase cinco séculos. E qual o cavaleiro errante cria dragões com os quais lutar: a crueza das serras agrestes, suas intempéries e a miséria que aflora nos rostos de seus agregados.

O nosso narrador-personagem o despe de sua túnica de cetim, dos tecidos macios e perfumados e lhe põe a armadura do Senhor de Tormes, o qual aufere foros e distribui graças aos seus vassalos. Descrê de tudo ou quase tudo que vê ou sente. Ao final, é narrado o retorno de Zé Fernandes de Paris e seu encontro com Jacinto na estação de Tormes. O narrador-personagem descreve Jacinto como altivo e belo. Um pater-famílias. É como se Zé Fernandes tivesse encontrado o molde perfeito, a quimera mais adequada para caracterizar o seu príncipe da grã-ventura.

\section{Resumo}

Este artigo pretende demonstrar o ceticismo do narradorpersonagem em A Cidade e as Serras de Eça de Queirós.

\section{Abstract}

This article intends to demonstrate the narrator-character's scepticism in Eça de Queiros's novel A Cidade as Serras. 